\title{
The Epidemic Spread of Seiridium cardinale on Leyland Cypress Severely Limits Its Use in the Mediterranean
}

R. Danti, S. Barberini, A. Pecchioli, V. Di Lonardo, and G. Della Rocca, Istituto per la Protezione delle Piante (IPP)-Consiglio Nazionale delle Ricerche (CNR), Via Madonna del Piano, I-50019, Sesto Fiorentino (FI), Italy

\begin{abstract}
Danti, R., Barberini, S., Pecchioli, A., Di Lonardo, V., and Della Rocca, G. 2014. The epidemic spread of Seiridium cardinale on Leyland cypress severely limits its use in the Mediterranean. Plant Dis. 98:1081-1087.

Leyland cypress ( $\times$ Hesperotropsis leylandii) is a fast-growing conifer used in most temperate regions as an ornamental tree for hedges and screens, and is one of the most commercially important trees in Europe. In recent years, severe diebacks and mortality due to cypress canker have been observed on Leyland cypress plantations in Southern Europe. This study was conducted to evaluate (i) the spread and impact of cypress canker caused by Seiridium cardinale in plantations of a sample area of $1,250 \mathrm{~km}^{2}$ in central Italy, (ii) the response of the most commonly grown Leyland cypress varieties to artificial inoculation with to $S$. cardinal, and (iii) the pathogenicity of $S$. cardinale isolates obtained from Leyland cypress. Of the 1,411 surveyed trees, $11.4 \%$ had been killed by cypress canker and $43.9 \%$ of the living trees were affected by the disease. The number of diseased or dead trees and the

percentage of cankered trunks was significantly correlated with the mean trunk diameter of the plantations. Six months after inoculation, the size of developed cankers was significantly different among the inoculated Leyland cypress cultivars but all of them showed markedly larger cankers than the $C$. sempervirens canker-resistant control clone. All of the tested $S$. cardinale isolates obtained from Leyland cypress also caused cankers on Cupressus sempervirens when inoculated as conidial suspensions or mycelia. Leyland cypress is highly prone to contract cypress canker in the Mediterranean due to its high susceptibility to $S$. cardinale infections, low genetic variability among the grown cultivars, and cracks which form on fast-growing trunks, favoring entry of the fungus into the inner bark and the occurrence of infections.
\end{abstract}

Leyland cypress is a fast-growing conifer of the family Cupressaceae. In view of its monocormic graceful habit, dense crown tolerant to intense pruning, adaptability to varied climatic and soil conditions, and tolerance to frost, pollution, and aerosols, it has been widely grown over the last few decades to form barriers, windbreaks, and hedges and as a shelter tree for private owners in parks and gardens (14). Leyland cypress has also been cultivated commercially as a Christmas tree and for wood products in most temperate regions $(3,18)$. In Italy, besides being used as an ornamental tree, Leyland cypress has been extensively utilized to screen highways, main roads, and railway lines in addition to industrial buildings and infrastructures, particularly over the last 10 to 20 years.

Leyland cypress is a hybrid, first raised in 1888 from a natural cross between Monterey Cypress (Hesperocyparis macrocarpa Hartw. Bartel) $\hat{\sigma}$ and Nootka or Alaskan Cypress (Callitropsis nootkatensis (D. Don) Florin) $q$ in Welshpool (Wales), named $\times$ Cupressocyparis leylandii (Dall. \& Jacks.) Dallimore in 1926 (19). The scientific name of Leyland cypress has changed repeatedly over the last two decades as a consequence of recurrent changes of the systematic position of both its parent species and, currently, $x$ Hesperotropsis leylandii is used $(1,21-23,39)$. However, for ease of understanding, in this article we will use the common name Leyland cypress.

Today, Leyland cypress is one of most widely sold trees in $\mathrm{Eu}-$ rope. In the United Kingdom, it accounted for $10 \%$ of nursery sales in 2008 (8). Italy has a long-standing tradition of Cupressaceae production, with an estimated 2.5 million Leyland cypress plants produced each year in nurseries in the Tuscan nursery district of Pistoia (Dr. Carlo Vezzosi, nurseryman in Pistoia at Giorgio Tesi

Corresponding author: G. Della Rocca, E-mail: dellarocca@ipp.cnr.it

Accepted for publication 27 February 2014.

http://dx.doi.org/10.1094/PDIS-12-13-1237-RE

(C) 2014 The American Phytopathological Society
Group, personal communication) for export to most Mediterranean and other European countries. More than 40 different cultivars, differing in growth rate, habit, color, and shape of the crown, have been created, although only about 10 are commonly available on the market (25). Germination of seed is rare and seedlings of the $\mathrm{F}_{2}$ generation have been raised infrequently (2); therefore, commercial trees are mainly produced through agamic propagation of the desired genotypes by cuttings and, less frequently, by grafting (6).

Leyland cypress is known to be susceptible to cypress canker caused by Seiridium spp. fungal pathogens in the southeastern states of the United States $(3,5,20,24,34,40,43)$ and in Oceania $(7,18,32,42)$. The disease was reported to affect Leyland cypress in the nurseries in central Italy as early as 1981 (29), and, to date, this remains the only report of Seiridium canker on this tree in Europe.

Seiridium canker, or bark canker of cypress, is a pandemic disease due to the worldwide spread of three pathogenic fungal species-Seiridium cardinale (W.W. Wagener) B. Sutton \& I.A.S. Gibson, S. cupressi (Guba) Boesew., and S. unicorne (Cooke \& Ellis) B. Sutton-that cause stem and branch necrosis, dieback, and tree mortality in most species of Cupressaceae $(9,15)$. S. cardinale, the most widespread and aggressive of the three fungi, was first reported in California in 1928 where, over a few years, it destroyed $H$. macrocarpa plantations in inland districts where this species was not native (44). In the following decades, the disease spread progressively over the five continents and gave rise to epidemics in many regions where it was introduced. In the Mediterranean, the extensive presence of susceptible hosts, in combination with climatic conditions conducive to the development of the pathogen, has promoted its rapid spread (15). Cypress canker reached an incidence as high as $70 \%$ in central Italy and Greece during the 1980s and severely affected the local cypress (Cupressus sempervirens L.) and other introduced cypress species such as $H$. macrocarpa. Epidemics caused the death of millions of trees, spoiled the landscape, and produced severe economic losses in woods, ornamental plantations, and nurseries $(15,28)$. Recent studies based on the use of both simple-sequence repeat and amplified fragment length polymorphism markers have suggested that California is the most likely source of the 
Mediterranean epidemics, and probably represents the area of origin of the pathogen $(12,13)$.

The optimal growth and germination of $S$. cardinale occurs at $25^{\circ} \mathrm{C}$, and it can be considered a mesophilic fungus suited to a warm-temperate climate (28). Although reported at relatively high latitudes in both hemispheres, the pathogen has only reached epidemic proportions in regions characterized by hot summers and cool and rainy winters. Indeed, there are few and limited reports of the disease from central Europe, England, Canada, or Chile $(17,27,36,41)$.

Since the mid-1970s, efforts were made in Central Italy to control the disease by sanitation to reduce the presence of the inoculum in the environment and also to launch a genetic improvement program aimed at selecting resistant lines of common cypress $(10,11)$. The adopted control measures have led to cypress canker currently approaching a post-epidemic or endemic phase, with a relatively steady prevalence (mean around $22 \%$ ) registered over the last few years in Tuscan woods and plantations of $C$. sempervirens (33). With the exception of particularly conducive sites, the occurrence of cypress canker caused by $S$. cardinale on $C$. sempervirens is generally milder and less frequent than in the past, although the fungus is now widespread throughout the territory.

Nevertheless, in recent years in Italy, from Lombardy and Veneto to Sicily, and especially in the central regions, severe diebacks and mortality have been observed with increasing frequency on Leyland cypress plantations disfigured by $S$. cardinale canker. Attacks rapidly develop on stems and branches, causing tree de- cline and death within a few years. Bark-canker-like symptoms have also been observed to affect this tree in other European countries such as France, Switzerland, and Spain (G. Della Rocca and R. Danti, unpublished data). In the course of a 2009 campaign for collecting the fungus from cankered species of Cupressaceae, severe symptoms were also observed throughout California on Leyland cypress trees planted at a distance from the coast (G. Della Rocca and M. Garbelotto, unpublished data). Despite Seiridium canker having been reported on Leyland cypress in many regions of the world, no studies to date have been addressed to evaluating its impact in terms of incidence and the extent of damage to plantations.

The aims of this study were to (i) evaluate the incidence and impact of cypress canker disease on Leyland cypress in a sample area of Central Italy, taking into account a representative number of plants; (ii) evaluate through artificial inoculations whether there are differences in susceptibility to cypress canker caused by $S$. cardinale among the current commercially available cultivars of Leyland cypress; and (iii) verify whether there are differences in pathogenicity between $S$. cardinale isolates from Leyland cypress and common cypress.

\section{Materials and Methods}

Surveys in Leyland cypress plantations. In total, 38 nonpruned Leyland cypress plantations of various ages and sizes over an area within a radius of about $20 \mathrm{~km}$ from Florence (metropolitan belt of Florence) were surveyed during spring to summer 2012 (Table 1). For each tree, the diameter of the trunk at $30 \mathrm{~cm}$

Table 1. List of the Leyland cypress plantations included in a $1,250-\mathrm{km}^{2}$ area around Florence and surveyed for Seiridium cardinale canker development ${ }^{2}$

\begin{tabular}{|c|c|c|c|c|c|c|}
\hline $\begin{array}{l}\text { Subzone, mean temperature } \\
\text { and rainfall }\end{array}$ & $\begin{array}{l}\text { Plantation } \\
\text { number }\end{array}$ & Municipality & $\begin{array}{c}\text { Elevation } \\
\text { (m above sea level) }\end{array}$ & Latitude N & Longitude E & $\begin{array}{l}\text { Number } \\
\text { of trees }\end{array}$ \\
\hline \multirow[t]{9}{*}{ 1, Bagno a Ripoli: $14.3^{\circ} \mathrm{C}, 975 \mathrm{~mm}$} & 1 & Bagno a Ripoli & 63 & $43^{\circ} 45^{\prime} 54^{\prime \prime}$ & $11^{\circ} 20^{\prime} 28^{\prime \prime}$ & 174 \\
\hline & 2 & Bagno a Ripoli & 70 & $43^{\circ} 44^{\prime} 14^{\prime \prime}$ & $11^{\circ} 17^{\prime} 43^{\prime \prime}$ & 85 \\
\hline & 3 & Bagno a Ripoli & 70 & $43^{\circ} 44^{\prime} 33^{\prime \prime}$ & $11^{\circ} 17^{\prime} 14^{\prime \prime}$ & 59 \\
\hline & 4 & Bagno a Ripoli & 90 & $43^{\circ} 46^{\prime} 31^{\prime \prime}$ & $11^{\circ} 21^{\prime} 46^{\prime \prime}$ & 23 \\
\hline & 5 & Bagno a Ripoli & 90 & $43^{\circ} 47^{\prime} 09^{\prime \prime}$ & $11^{\circ} 22^{\prime} 59^{\prime \prime}$ & 42 \\
\hline & 26 & Pontassieve & 105 & $43^{\circ} 46^{\prime} 32^{\prime \prime}$ & $11^{\circ} 26^{\prime} 14^{\prime \prime}$ & 15 \\
\hline & 27 & Rignano sull'Arno & 260 & $43^{\circ} 47^{\prime} 08^{\prime \prime}$ & $11^{\circ} 23^{\prime} 33^{\prime \prime}$ & 37 \\
\hline & 28 & Rignano sull'Arno & 350 & $43^{\circ} 43^{\prime} 26^{\prime \prime}$ & $11^{\circ} 23^{\prime} 14^{\prime \prime}$ & 16 \\
\hline & 29 & Rignano sull'Arno & 180 & $43^{\circ} 41^{\prime} 50^{\prime \prime}$ & $11^{\circ} 24^{\prime} 35^{\prime \prime}$ & 53 \\
\hline \multirow[t]{7}{*}{ 2, Lastra a Signa: $14.6^{\circ} \mathrm{C}, 914 \mathrm{~mm}$} & 23 & Lastra a Signa & 140 & $43^{\circ} 44^{\prime} 41^{\prime \prime}$ & $11^{\circ} 04^{\prime} 49^{\prime \prime}$ & 15 \\
\hline & 24 & Lastra a Signa & 140 & $43^{\circ} 44^{\prime} 19^{\prime \prime}$ & $11^{\circ} 04^{\prime} 26^{\prime \prime}$ & 19 \\
\hline & 25 & Lastra a Signa & 40 & $43^{\circ} 46^{\prime} 01^{\prime \prime}$ & $11^{\circ} 07^{\prime} 09^{\prime \prime}$ & 11 \\
\hline & 32 & San Casciano & 80 & $43^{\circ} 41^{\prime} 06^{\prime \prime}$ & $11^{\circ} 08^{\prime} 01^{\prime \prime}$ & 13 \\
\hline & 33 & San Casciano & 100 & $43^{\circ} 40^{\prime} 41^{\prime \prime}$ & $11^{\circ} 07^{\prime} 07^{\prime \prime}$ & 9 \\
\hline & 34 & Scandicci & 74 & $43^{\circ} 44^{\prime} 28^{\prime \prime}$ & $11^{\circ} 10^{\prime} 30^{\prime \prime}$ & 90 \\
\hline & 36 & Signa & 36 & $43^{\circ} 47^{\prime} 41^{\prime \prime}$ & $11^{\circ} 06^{\prime} 22^{\prime \prime}$ & 82 \\
\hline \multirow[t]{5}{*}{ 3, Sesto F.no $14.5^{\circ} \mathrm{C}, 997 \mathrm{~mm}$} & 8 & Calenzano & 72 & $43^{\circ} 51^{\prime} 42^{\prime \prime}$ & $11^{\circ} 10^{\prime} 23^{\prime \prime}$ & 46 \\
\hline & 9 & Calenzano & 112 & $43^{\circ} 53^{\prime} 50^{\prime \prime}$ & $11^{\circ} 11^{\prime} 01^{\prime \prime}$ & 47 \\
\hline & 10 & Calenzano & 400 & $43^{\circ} 56^{\prime} 47^{\prime \prime}$ & $11^{\circ} 12^{\prime} 47^{\prime \prime}$ & 43 \\
\hline & 11 & Campi Bisenzio & 38 & $43^{\circ} 49^{\prime} 30^{\prime \prime}$ & $11^{\circ} 07^{\prime} 49^{\prime \prime}$ & 23 \\
\hline & 35 & Sesto Fiorentino & 72 & $43^{\circ} 50^{\prime} 03^{\prime \prime}$ & $11^{\circ} 12^{\prime} 18^{\prime \prime}$ & 37 \\
\hline \multirow[t]{8}{*}{ 4, Borgo San Lorenzo: $13.4^{\circ} \mathrm{C}, 996 \mathrm{~mm}$} & 6 & Barberino di Mugello & 270 & $44^{\circ} 00^{\prime} 13^{\prime \prime}$ & $11^{\circ} 14^{\prime} 18^{\prime \prime}$ & 15 \\
\hline & 7 & Barberino di Mugello & 210 & $43^{\circ} 57^{\prime} 52^{\prime \prime}$ & $11^{\circ} 17^{\prime} 37^{\prime \prime}$ & 59 \\
\hline & 30 & Rufina & 150 & $43^{\circ} 51^{\prime} 41^{\prime \prime}$ & $11^{\circ} 31^{\prime} 35^{\prime \prime}$ & 16 \\
\hline & 31 & Rufina & 114 & $43^{\circ} 49^{\prime} 46^{\prime \prime}$ & $11^{\circ} 29^{\prime} 00^{\prime \prime}$ & 10 \\
\hline & 37 & Vaglia & 347 & $43^{\circ} 52^{\prime} 31^{\prime \prime}$ & $11^{\circ} 17^{\prime} 32^{\prime \prime}$ & 37 \\
\hline & 38 & Vicchio del Mugello & 200 & $43^{\circ} 53^{\prime} 18^{\prime \prime}$ & $11^{\circ} 26^{\prime} 53^{\prime \prime}$ & 19 \\
\hline & 12 & Fiesole & 164 & $43^{\circ} 50^{\prime} 03^{\prime \prime}$ & $11^{\circ} 18^{\prime} 31^{\prime \prime}$ & 11 \\
\hline & 13 & Fiesole & 161 & $43^{\circ} 48^{\prime} 10^{\prime \prime}$ & $11^{\circ} 17^{\prime} 14^{\prime \prime}$ & 22 \\
\hline \multirow[t]{9}{*}{ 5, Firenze airport: $14.6^{\circ} \mathrm{C}, 910 \mathrm{~mm}$} & 14 & Firenze & 41 & $43^{\circ} 46^{\prime} 19^{\prime \prime}$ & $11^{\circ} 12^{\prime} 29^{\prime \prime}$ & 4 \\
\hline & 15 & Firenze & 40 & $43^{\circ} 46^{\prime} 39^{\prime \prime}$ & $11^{\circ} 10^{\prime} 16^{\prime \prime}$ & 19 \\
\hline & 16 & Firenze & 40 & $43^{\circ} 46^{\prime} 39^{\prime \prime}$ & $11^{\circ} 10^{\prime} 16^{\prime \prime}$ & 72 \\
\hline & 17 & Firenze & 68 & $43^{\circ} 43^{\prime} 11^{\prime \prime}$ & $11^{\circ} 13^{\prime} 25^{\prime \prime}$ & 44 \\
\hline & 18 & Firenze & 70 & $43^{\circ} 44^{\prime} 40^{\prime \prime}$ & $11^{\circ} 17^{\prime} 07^{\prime \prime}$ & 16 \\
\hline & 19 & Firenze & 40 & $43^{\circ} 46^{\prime} 59^{\prime \prime}$ & $11^{\circ} 11^{\prime} 20^{\prime \prime}$ & 7 \\
\hline & 20 & Firenze & 40 & $43^{\circ} 46^{\prime} 54^{\prime \prime}$ & $11^{\circ} 11^{\prime} 14^{\prime \prime}$ & 8 \\
\hline & 21 & Firenze & 40 & $43^{\circ} 46^{\prime} 24^{\prime \prime}$ & $11^{\circ} 11^{\prime} 59^{\prime \prime}$ & 87 \\
\hline & 22 & Firenze & 40 & $43^{\circ} 46^{\prime} 20^{\prime \prime}$ & $11^{\circ} 11^{\prime} 40^{\prime \prime}$ & 26 \\
\hline Total & $\ldots$ & $\ldots$ & $\ldots$ & $\ldots$ & $\ldots$ & 1,411 \\
\hline
\end{tabular}

${ }^{\mathrm{z}}$ Plantations were distributed in five subzones based on the topographical features of territory (see text). For each subzone, the mean annual temperature and the mean annual rainfall recorded in the period 2003 to 2012 in a representative site were reported, referring to data collected in the archives of Il Meteo (www.ilmeteo.it) and of the Regional Hydrologic Service (www.cfr.toscana.it). 
above the ground (as semi-sum of two perpendicular diameters) and height were measured. The conditions of health of each tree were recorded, with particular reference to symptoms of $S$. cardinale attacks, taking into account the development of the disease on affected trees (i.e., the affected organs: trunk, branches, or twigs) and extent of damaged crown (in percent). The latter parameter was estimated visually, subdividing the crowns into 10 classes from 0 to 10 to 91 to $100 \%$ based on the quantity of discolored or dead crown, following the procedure described by Stone et al. (35) for determining the extent of necrotized area of Eucalypt leaves.

Isolation and identification of the pathogen. From the Leyland cypress trees showing typical bark canker symptoms, twig, branch, or stem samples were cut and brought to the laboratory. Isolation of the fungal pathogen $S$. cardinale was carried out within 24 h by plating small (about $10 \mathrm{~mm}^{2}$ ) fragments of necrotic bark cut from the margins of branch or stem cankers on potato dextrose agar (PDA). White to gray or olive, cottony colonies with a salmonorange reverse side, grown from the plated fragments after an incubation of 3 to 4 days at $25^{\circ} \mathrm{C}$ in the dark, were separately transferred onto $1 \%$ malt extract agar (malt extract at $10 \mathrm{~g} / \mathrm{liter}+$ agar at $20 \mathrm{~g} / \mathrm{liter}$ ) supplemented with autoclaved cypress seed. The plates were then incubated at $18^{\circ} \mathrm{C}$ under mixed white and near-ultraviolet light (400 to $200 \mathrm{~nm}$ ), set to provide 12-h light and dark cycles to induce sporulation of the fungus. For each isolate, seed-bearing acervuli were put inside sterile and hermetic plastic tubes and stored at $-20^{\circ} \mathrm{C}$.

The identity of the fungal isolates was determined based on the morphology of conidia suspended in water and observed under light microscope at $\times 400(7,26,38,45)$ and confirmed by sequence analysis of the $\beta$-tubulin locus performed as described by Della Rocca et al. (12) and Barnes et al. (4). The DNA sequences of a $\beta$ tubulin portion of all 45 isolates obtained from necrotic Leyland cypress bark samples and of the $S$. cardinale American Type Culture Collection (ATCC) isolate 38654 used as reference showed from 98 to $100 \%$ homology with sequences of $S$. cardinale isolates from Italy and Greece deposited in GenBank (accessions HQ678147 and HQ678149, respectively), while they were clearly distinct from sequences deposited for an S. cupressi isolate from Greece (accession AF320492) and an S. unicorne (accession AF320482) isolate from Portugal.

Susceptibility of Leyland cypress cultivars to $S$. cardinale. The susceptibility to $S$. cardinale infections of five of the Leyland cypress cultivars most widely grown by Italian nurseries was evaluated through artificial inoculations on stems. The assessed cultivars were 'Leighton green' (common Leylandii), 'Castlewellan Gold', 'Variegatus', 'Gold Rider', and 'Piramidalis 2001'. For each cultivar, 10 3-year-old plants obtained from rooted cuttings and grown in 15-liter pots containing a mixture of peat compost and perlite (3:1:1, vol/vol/vol) were inoculated in April 2012. The plants had a mean trunk diameter of $3.2 \mathrm{~cm}$ at collar level and a mean height of $1.75 \mathrm{~m}$. Inoculations were carried out on stems where the diameter was about $1.5 \mathrm{~cm}$ using the $S$. cardinale standard isolate ATCC 38654 by removing a $3-\mathrm{mm}$-diameter circular plug of bark using a cork borer and replacing it with a plug of the same size taken from the margin of a colony of the fungus grown on PDA for 2 weeks at $25^{\circ} \mathrm{C}$ in the dark. The inoculation site was covered with cotton and wrapped with tape, both of which were removed after 1 week. Ten grafted plants of the same age as the C. sempervirens clone 'Agrimed n.1', patented as resistant to cypress canker caused by $S$. cardinale, were also inoculated as described above and used as a control sample. After being inoculated, the plants were kept in a tunnel for 6 months under $50 \%$ shade netting and were regularly irrigated to field capacity three times a week. The development of cankers on inoculated stems was evaluated in October 2012, 6 months after inoculation. The cankered portions of stems were cut, put separately into plastic bags, and processed in the laboratory within $24 \mathrm{~h}$. The outer bark was removed in order to expose the margin of the cankers and to measure the length and width of the necrotic area. Isolation of the inoculated fungus was performed from a sample of induced cankers.
Pathogenicity of $S$. cardinale isolates from Leyland cypress. Artificial inoculations were carried out on C. sempervirens trees to assess the ability of $S$. cardinale isolates obtained from Leyland cypress to cause cankers on common cypress. Ten isolates obtained from heavily cankered Leyland cypress plantations were used in this trial along with S. cardinale ATCC 38654 and Sc 404 (Istituto per la Protezione delle Piante [IPP]-Consiglio Nazionale delle Ricerche culture collection) from $C$. sempervirens used as a reference. Inoculations were executed in April 2012 following the procedure described in the previous paragraph, on branches of $17-$ year-old $C$. sempervirens grafted trees growing in the field at the IPP farm situated in Antella (Florence). Four branches located in the lower-mid portion of the crown of each tree were separately inoculated where the diameter was around 1.5 to $2 \mathrm{~cm}$. For each isolate, 10 branches randomly selected among 15 trees were inoculated.

Inoculations were also carried out using conidial suspensions of the same isolates on stems of 3-year-old C. sempervirens grafted saplings growing in 3.5-liter pots containing a mixture of peat compost and perlite $(3: 1: 1, \mathrm{vol} / \mathrm{vol} / \mathrm{vol})$. For each isolate, conidia were obtained as described above ('Isolation of the pathogen'). Conidia were suspended in $0.3 \%$ water agar (WA) inside $1.5-\mathrm{ml}$ microcentrifuge tubes, adjusting the concentration to $1 \times 10^{5}$ conidia $\mathrm{ml}^{-1}$ by using a hemocytometer (Burker chamber). For each plant, two 5-mm-diameter wounds extending into the cambium made on stems with a cork borer (at a distance of at least $20 \mathrm{~cm}$ from each other) were inoculated in April 2012 with $100 \mu \mathrm{l}$ of conidial suspension prepared for all the assessed isolates. The inoculation site was covered with cotton and parafilm, which was then removed after 2 weeks. Ten plants were inoculated for each isolate. On 10 further control plants, $100 \mu \mathrm{l}$ of sterile WA was applied to the wounds, which were then covered with cotton and parafilm as described above. After inoculation, the plants were kept in a tunnel under 50\% shade netting and were regularly watered to field capacity three times a week. Assessment of inoculations that resulted in infections on the inoculated stems were carried out after 60 days.

Statistics. Plantations in the surveyed area were assigned to five geographical subzones, reflecting the morphology (topographical features) of the territory. The southeastern subzone located east of Florence, south of the Arno river (subzone 1); the southwestern subzone located south of Florence between the Arno river and the valley of the Pesa river (subzone 2); the subzone located on the northwest slopes of the plane of Florence (subzone 3); the subzone located north of Florence in the valley of the Sieve river and separated from the city by a mountain range with elevation of $1,000 \mathrm{~m}$ (subzone 4); and the subzone comprising the plane of Florence (subzone 5). For each subzone, the plantations were also subdivided into five classes based on the mean trunk diameter to evaluate the effect of the size of plantations on the frequency of diseased trees (Table 2). Percentages of diseased trees were calculated for each of the five subzones and each class of trunk diameter. Differences among subzones and trunk diameter classes were separately evaluated through the $\chi^{2}$ test based on five-by-two contingency tables in which the proportion between diseased and healthy trees was considered.

The Pearson correlation coefficient was calculated to explore the relationship between elevation and the frequency of diseased trees in each plantation. Correlations between the mean trunk diameter of each plantation and the frequency (in percent) of diseased trees, the frequency of trees with cankered trunks, the frequency of dead trees, and the mean extent of crown damage were also studied.

The differences in size of the cankers developed on the inoculated Leyland cypress cultivars were calculated through analysis of variance and the post-hoc honestly significant difference (HSD) Tukey test. Percent values of necrotized trunk circumference were subjected to angular transformation using the formula $y=\arcsin$ $\sqrt{ }(p / 100)$, where $p$ is the percentage of necrotized trunk circumference, before being analyzed. Analysis of variance and the posthoc HSD Tukey test were also used to explore differences in size 
of the cankers developed on $C$. sempervirens trees inoculated with $S$. cardinale isolates derived from Leyland cypress and common cypress (analysis of variance and post hoc tests were performed using the software package STATISTICA 7.0).

\section{Results}

Survey on Leyland cypress plantation. In total 1,411 Leyland cypress trees belonging to 38 plantations were surveyed for symptoms of bark canker (Table 1). Acervuli of the fungus were observed on the bark of most cankered stems and branches along with abundant resin exudation. Of the living trees, $43.9 \%$ were affected by cypress canker due to $S$. cardinale and $11.4 \%$ of the original planted trees had died as consequence of the attacks by the pathogen (Table 2).

Significant differences in the frequency of diseased trees were observed among the five subzones: the highest value $(54.5 \%)$ was registered for subzone 1 and the lowest $(9.7 \%)$ for subzone $3\left(\chi^{2}=\right.$ 188.1; df $4 ; P<0.01)$. The frequency of diseased trees was also significantly different among the five diametric classes to which the plantations were assigned by mean trunk diameter $\left(\chi^{2}=84.7\right.$; gdl 4; $P<0.01)$. More specifically, a clear increase in the percentage of affected trees (from 32.6 to 69.6\%) was associated with an increase in diameter of the trunk.
No significant correlation was observed between the percentage of affected trees and the elevation of each plantation $(r=0.16 ; P>$ $0.05)$. Instead, the mean diameter of trunk of each plantation was positively and significantly related to the percentage of diseased trees $(r=0.622 ; P<0.01)$, the percentage of trees with cankered trunks $(r=0.403 ; P<0.05)$, the percentage of dead trees $(r=$ $0.309 ; P<0.01)$, and the extent of crown damage $(r=0.363 ; P<$ 0.05) (Fig. 1).

Susceptibility of some Leyland cypress cultivars to $S$. cardinale infections. The size of cankers developed 6 months after inoculation with $S$. cardinale mycelium on stems of various Leyland cypress cultivars is reported in Table 3. Both the mean length and width of resultant cankers varied significantly $(P<$ 0.01) among the Leyland cypress cultivars considered. In detail, longer cankers were observed on Variegatus and Leighton green whereas, on Castlewellan Gold, cankers were not significantly longer than those observed on the resistant control cypress clone Agrimed n.1. Cankers developed on all Leyland cypress cultivars were markedly wider than those developed on the resistant control $(P<0.01)$. Wider cankers $(P<0.01)$ were observed on Gold Rider, Leighton green, and Variegatus compared with the Castlewellan Gold, while Piramidalis 2001 showed an intermediate width of cankers.

Table 2. Frequency of diseased trees (referred to number of trees affected by Seiridium cardinale canker on the number of living trees) was displayed for each of the five subzones and for each of the five diametric classes to which plantations were assigned according to their mean trunk diameter measured 30 $\mathrm{cm}$ above the ground ${ }^{\mathrm{y}}$

\begin{tabular}{|c|c|c|c|c|c|c|c|}
\hline \multirow[b]{2}{*}{ Subzone } & \multicolumn{5}{|c|}{ Frequency of diseased trees per diametric class } & \multirow[b]{2}{*}{ Diseased $(\%)$} & \multirow[b]{2}{*}{ Dead $(\%)$} \\
\hline & $5-10 \mathrm{~cm}$ & $11-15 \mathrm{~cm}$ & $16-20 \mathrm{~cm}$ & $21-25 \mathrm{~cm}$ & $>25 \mathrm{~cm}$ & & \\
\hline 1 & $103 / 180$ & $10 / 35$ & $14 / 33$ & $100 / 174$ & $9 / 11$ & 54.5 & 14.0 \\
\hline 2 & $25 / 117$ & $-1-$ & $7 / 13$ & $10 / 26$ & $56 / 89$ & 42.4 & 6.4 \\
\hline 3 & $16 / 164$ & $-1-$ & $-1-$ & $-1-$ & $-1-$ & 9.7 & 5.2 \\
\hline 4 & $-1-$ & $17 / 44$ & $28 / 67$ & $11 / 33$ & $-1-$ & 38.8 & 13.7 \\
\hline 5 & $37 / 93$ & $11 / 22$ & $19 / 54$ & $7 / 7$ & $63 / 88$ & 51.9 & 13.4 \\
\hline Diseased (\%) & 32.6 & 39.4 & 39.6 & 55.2 & 69.6 & $43.9^{\mathrm{z}}$ & $11.4^{\mathrm{z}}$ \\
\hline
\end{tabular}

y Percentages of both diseased and dead trees (the latter referred to the total number of trees of the original plantation) were also reported for each subzone. ${ }^{\mathrm{z}}$ Overall.

\section{A}
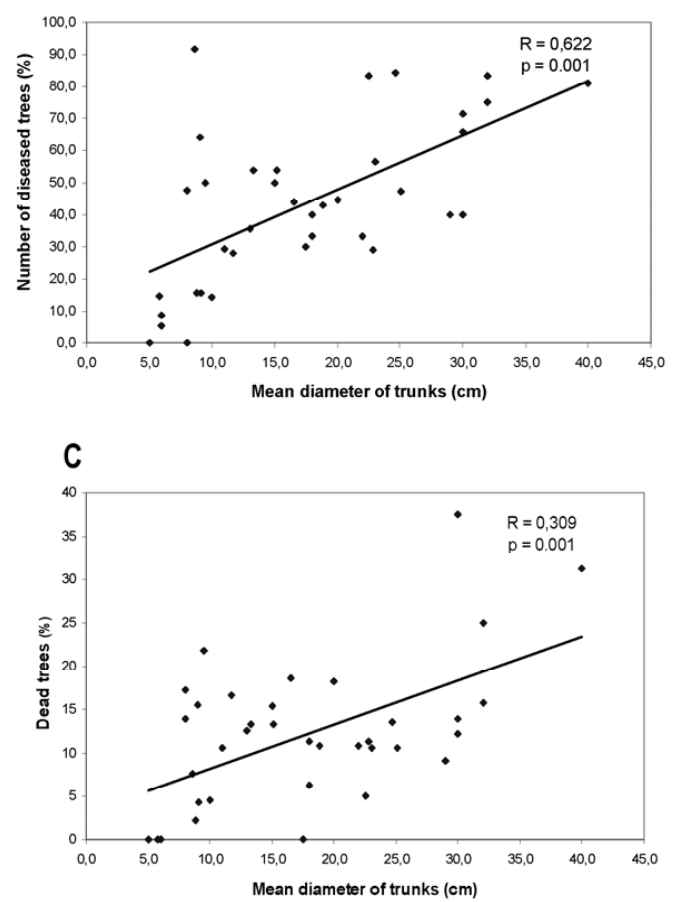
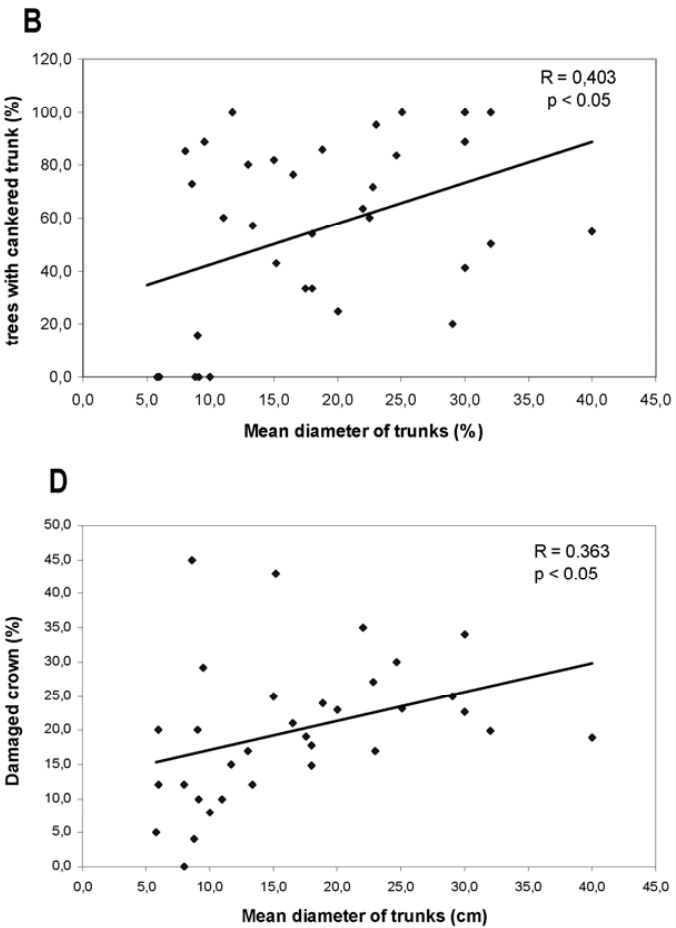

Fig. 1. Correlation between mean diameter of trunk of each of the surveyed Leyland cypress plantation and $\mathbf{A}$, number of Seiridium cardinale-diseased trees as percentage of the living trees; B, number of trees with cankered trunk as percentage of the diseased trees; C, number of killed trees as percentage of the total number of trees; and D, extent of damaged crown in percent (as mean of the values registered on the diseased trees of each plantation). 
In terms of the percentage of necrotized trunk circumference (the ratio between the width of cankers and the trunk circumference), a clear and significant difference emerged between the resistant control clone (36.7\%) and all the Leyland cypress cultivars considered (from $76.7 \%$ of Castlewellan Gold to $98.0 \%$ of Leighton green; Table 3). A significant difference was also observed when comparing Variegatus and Leighton green, which showed values close to $100 \%$ (which means complete girdling of stem) with Castlewellan Gold.

Pathogenicity of $S$. cardinale isolates from Leyland cypress. All artificial inoculations with mycelium of isolates from Leyland cypress successfully caused cankers on branches of $C$. sempervirens. Significant differences were observed 6 months after inoculation in both the length and width of cankers among isolates from Leyland cypress, whereas cankers generated by the reference isolate ATCC 38654 from C. sempervirens were not significantly different from those produced by isolates from Leyland cypress (Table 4).

All five tested $S$. cardinale isolates from Leyland cypress produced necrotic lesions when inoculated through conidial suspensions on stems of 3-year-old saplings of C. sempervirens (Table 5).

\section{Discussion}

Observations carried out from the north to the south of Italy, and an in-depth survey conducted over a restricted area in central Italy, on a wide sample of Leyland cypress plantations has demonstrated that this tree is prone to attack and disfigurement by cypress canker due to $S$. cardinale. Of the 1,411 surveyed trees, $11.4 \%$ had been killed by cypress canker and $43.9 \%$ of the living trees were affected by the disease. Of 38 surveyed plantations, 12 exhibited a prevalence of diseased trees greater than $50 \%$ and, in some cases, the frequency of diseased trees was as high as 80 or $90 \%$. This high percentage of attacked trees, along with the severe damage to crowns reported in most plantations, confirms that Leyland cypress is highly vulnerable to $S$. cardinale. The fungus may easily colonize an infected tree and spread rapidly to other trees; thus, $S$. cardinale represents a limiting factor for cultivation in the climatic conditions of central Italy.

The susceptibility of Leyland cypress to Seiridium canker was already known, because cankers and severe dieback were reported in the Great Plains states of the south-central and southeastern United States (Georgia, Florida, Arkansas, Texas, and North and South Carolina) in addition to California and New Zealand $(3,18,20,24,34,40,42,44)$.

Despite the fact that Seiridium cankers were reported as severely affecting Leyland cypress in various regions of the world, to date, no studies have focused on evaluating the distribution of the disease and quantifying the extent of damage over a specific territory in order to define the real impact of the disease on this tree. This work aims to evaluate the distribution and development of $S$. cardinale attacks, and the extent of damage to plantations over an area of $1,250 \mathrm{~km}^{2}$ around the city of Florence. Over the past few decades, this tree has been extensively planted in this region and, since the 1970s, the pathogen has caused serious epidemics on $C$. sempervirens. The occurrence of virulent and spreading infection of Leyland cypress is in contrast to the endemic (or post-epidemic) phase that $S$. cardinale canker is currently exhibiting in the Italian cypress in the surveyed territory and over central Italy. Furthermore, excluding some sites with microclimatic conditions that prove to be particularly conducive to the spread of the pathogen, attacks on $C$. sempervirens are generally sporadic in this region (22\% mean prevalence of the disease in Tuscany; 33 ).

A different prevalence of diseased trees was revealed among the five subzones into which the surveyed area was divided, and a clear rise in the frequency of diseased trees was also observed with the increase of the mean diameter of plantations. Unfortunately, the trunk diameter classes into which the plantations were grouped were not evenly distributed among the five subzones (e.g., all plantations in subzone 3 belonged to the smaller diametric class) and, for this reason, it was difficult to separate the effect of site (local climate) from the effect of the size of plantations. The collected climatic data showed that both the mean temperature and the mean annual rainfall of the five subzones are very similar and, even though a site effect cannot be ruled out, differences in the percentage of affected trees observed within the studied area can be ascribed mostly to the size of plantations in the subzones. The absence of a relationship between elevation and the percentage of

Table 4. Mean development of necrotic lesions on branches of 17 -year-old Cupressus sempervirens trees measured 6 months after artificial inoculation with Seiridium cardinale isolates obtained from Leyland cypress ${ }^{\mathrm{z}}$

\begin{tabular}{lccc}
\hline Isolate & Host of origin & $\begin{array}{c}\text { Canker length } \\
(\mathbf{m m})\end{array}$ & $\begin{array}{c}\text { Canker width } \\
(\mathbf{m m})\end{array}$ \\
\hline Sc ATCC 38654 & C. sempervirens & $25.8 \mathrm{ab}$ & $11.4 \mathrm{ab}$ \\
Sc 404 & C. sempervirens & $33.0 \mathrm{ab}$ & $10.8 \mathrm{ab}$ \\
Sc 519 & Leyland cypress & $26.2 \mathrm{ab}$ & $9.3 \mathrm{a}$ \\
Sc 520 & Leyland cypress & $23.1 \mathrm{ab}$ & $10.5 \mathrm{ab}$ \\
Sc 526 & Leyland cypress & $33.7 \mathrm{ab}$ & $13.7 \mathrm{~b}$ \\
Sc 527 & Leyland cypress & $17.4 \mathrm{a}$ & $9.1 \mathrm{a}$ \\
Sc 529 & Leyland cypress & $17.6 \mathrm{a}$ & $13.5 \mathrm{~b}$ \\
Sc 530 & Leyland cypress & $32.5 \mathrm{ab}$ & $12.0 \mathrm{ab}$ \\
Sc 533 & Leyland cypress & $38.0 \mathrm{~b}$ & $12.5 \mathrm{ab}$ \\
Sc 535 & Leyland cypress & $23.9 \mathrm{ab}$ & $10.9 \mathrm{ab}$ \\
Sc 536 & Leyland cypress & $27.8 \mathrm{ab}$ & $11.0 \mathrm{ab}$ \\
Sc 537 & Leyland cypress & $30.2 \mathrm{ab}$ & $12.1 \mathrm{ab}$ \\
\hline
\end{tabular}

${ }^{\mathrm{z}}$ Isolates ATCC 38654 and Sc 404 from C. sempervirens were included as reference. Means not sharing same letters within each column were significantly different for $P<0.05$ according to Tukey's honestly significant difference test.

Table 5. Number of positive infections (out of 20 inoculations) developed 60 days after stem inoculation of 3-year-old Cupressus sempervirens plants using conidial suspensions of Seiridium cardinale isolates obtained from Leyland cypress ${ }^{\mathrm{Z}}$

\begin{tabular}{llc}
\hline Isolate & Host of origin & Number of positive infections \\
\hline ATCC 38654 & C. sempervirens & $16 / 20$ \\
Sc 526 & Leyland cypress & $14 / 20$ \\
Sc 527 & Leyland cypress & $20 / 20$ \\
Sc 533 & Leyland cypress & $16 / 20$ \\
Sc 535 & Leyland cypress & $12 / 20$ \\
Sc 536 & Leyland cypress & $14 / 20$ \\
Control & $\ldots$ & $0 / 20$ \\
\hline
\end{tabular}

${ }^{\mathrm{z}}$ Isolate ATCC 38654 derived from common cypress was included as reference. Control $=$ sterile agar.

Table 3. Mean development of necrotic lesions on stems of 3-year-old plants of Leyland cypress and Common cypress as control measured 6 months after artificial inoculation with the ATCC 38654 isolate of Seiridium cardinale ${ }^{\mathrm{Z}}$

\begin{tabular}{|c|c|c|c|}
\hline Cultivar, species & Length (cm) & Width (cm) & Necrotized trunk circumference $(\%)$ \\
\hline Cupressus sempervirens 'Agrimed n.1' & $8.44 \mathrm{ab}$ & $2.45 \mathrm{a}$ & $36.7 \mathrm{a}$ \\
\hline \multicolumn{4}{|l|}{ Leyland cypress } \\
\hline 'Castlewellan gold' & $6.24 \mathrm{a}$ & $5.17 \mathrm{~b}$ & $76.7 \mathrm{~b}$ \\
\hline 'Pyramidalis 2001' & $11.33 \mathrm{~b}$ & $5.42 \mathrm{bc}$ & $86.5 \mathrm{bc}$ \\
\hline 'Gold rider' & $9.18 \mathrm{ab}$ & $5.86 \mathrm{c}$ & $84.6 \mathrm{bc}$ \\
\hline 'Leighton Green', & $11.80 \mathrm{~b}$ & $6.82 \mathrm{c}$ & $98.8 \mathrm{c}$ \\
\hline ‘Variegatus' & $11.24 \mathrm{~b}$ & $7.09 \mathrm{c}$ & $95.2 \mathrm{c}$ \\
\hline
\end{tabular}

${ }^{\text {z }}$ Means not sharing same letters within each column were significantly different for $P<0.01$ according to Tukey's honestly significant difference test. 
diseased trees in the study area failed to confirm any potential effect of climate variation at a local level on the spread of cypress canker in Leyland cypress. Furthermore, Leyland cypress plantations currently appear to be severely affected by bark canker throughout Italy, in both the north and south, where climatic conditions are markedly different.

The study also revealed a significant positive correlation between the mean percentage of damaged crown (within diseased trees), the percentage of cankered trunks and dead trees, and the size of Leyland cypress plantations. The younger plantations (2 to $4 \mathrm{~m}$ tall) were generally mildly affected by $S$. cardinale. This is not consistent with the higher susceptibility to $S$. cardinale infections that is reported in literature for young cypress trees or on twigs and small branches (28). S. cardinale infections generally occur more frequently on young twigs or on small plants that have a thin outer bark and are more subject to microlesions (due to cold, insects, hail, and so on) through which the pathogen may enter the inner bark and begin the infection process. We have observed that the outer bark of Leyland cypress remains smooth on small trunks and branches; however, the very rapid diametric growth of this tree causes the occurrence of visible cracks on trunks when they reach a diameter of 8 to $10 \mathrm{~cm}$. The bark is probably subjected to excessive tension due to the intense growth of the xylem and, consequently, tends to crack and fissure. Frequently, trunks exceeding 10 to $15 \mathrm{~cm}$ in diameter are characterized by visible cracks that expose the inner bark. This can favor the entrance of the pathogen into the host tissues, and can explain the higher number of cankered trunks and the more severe damage observed in older plantations in the present survey.

As an intergeneric and sterile hybrid, raised in relatively recent times (19th century), this tree has theoretically not experienced coevolution with any pathogens or other stress factors and, at the same time, has inherited the susceptibility to $S$. cardinale from at least one of its parents. Nothing is known about the response of Nootka cypress to $S$. cardinale infections. This species, due to its Northern range along the Pacific coast from northern California to Alaska, has never been reported as host of the pathogen, which is ecologically suited to warm-temperate regions. However, Nootka cypress could be susceptible to $S$. cardinale when cultivated outside its native area in regions adapted to the development of the fungus, which has a wide range of hosts among species of Cupressaceae. The other parent species, Monterey cypress (H. macrocarpa), while not attacked by $S$. cardinale in its native habitat (a restricted area facing the Pacific coast near Monterey in California), is known for its extreme susceptibility to the fungus when grown in warm-temperate regions. Monterey cypress plantations have been reported to be severely affected or compromised by Seiridium cankers since the first half of the last century in inland California, and in the Mediterranean, New Zealand, Australia, and South Africa $(28,37,38,45,46)$. Additionally, in terms of the response of Monterey cypress to $S$. cardinale infections, artificial inoculation campaigns conducted in Italy and France also revealed a substantial lack of intraspecific variability in the resistance response to the pathogen. All young stems were completely girdled by the induced cankers, and trees were not able to survive the inoculation $(16,30,31)$.

It is likely that bark cracks that appear on trunks when they exceed a certain diameter represent a limiting factor for the growth of this tree in regions where the climatic conditions are favorable to $S$. cardinale. Although most of the surveyed plantations were located several kilometers away from one another, the high density of susceptible hosts and the long-established presence of the fungus in the studied area could have favored the spread of the disease in Leyland cypress, as observed in the survey. Furthermore, Leyland cypress has also recently appeared to be severely affected by $S$. cardinale throughout inland California, although this tree and other susceptible members of the family Cupressaceae (i.e., Monterey cypress and Italian cypress) are sparsely distributed in the territory, mainly as ornamentals in parks and gardens (G. Della Rocca and M. Garbelotto, unpublished data). We have observed that there was no apparent relationship between the number of trees and the percentage of diseased trees in each plantation (data not shown). This seems to corroborate the marked propensity of Leyland cypress to contract bark canker, even when the level of the inoculum is relatively low, provided that climatic conditions are favorable to the pathogen.

Leyland cypress can be used successfully in regions where Seiridium inoculum is absent or very scarce, such as in north-central Europe, where the climate is relatively cold and unsuited to the spread of the pathogen. However, in the Mediterranean, Leyland cypress growth can be severely conditioned by attacks of the fungus, even where the disease has become endemic on the local common cypress. Indeed, many of the older plantations of Leyland cypress included in the survey appeared devastated, and their ornamental or screening functions substantially negated.

Artificial inoculation with the $S$. cardinale isolate ATCC 38654 showed a greater development of necrotic lesions on all the tested Leyland cypress varieties than on the $C$. sempervirens canker-resistant control clone. Significant differences were observed in both the length and width of necrosis among the various Leyland cypress cultivars. In particular necrosis was significantly less developed on Castlewellan Gold compared with all the other tested cultivars. Greater differences were observed in the width (and percentage of necrotized trunk circumference) rather than the length of cankers among the various Leyland cypress cultivars and the common cypress resistant clone. The pathogen showed rapid lateral growth on Leyland cypress and, 6 months after inoculation, 76.7 to $98.8 \%$ of the trunk circumference was affected by the necrosis whereas, on the C. sempervirens-resistant clone, only $36.7 \%$ of the trunk circumference was necrotized. The rapid lateral spread of the fungus in the bark tissues observed in artificially inoculated Leyland cypress trees means that trunks and branches can be easily girdled by cankers, explaining the severity of damage observed in most plantations. In summary, none of the tested varieties of Leyland cypress seemed to show some form of resistance against cypress canker caused by $S$. cardinal; however, a proper assessment of their response would require longer-term observations.

All of the assayed $S$. cardinale isolates obtained from Leyland cypresses showed the ability to produce necrotic lesions when inoculated on $C$. sempervirens. No significant differences were noted 6 months after mycelial inoculation in regard to the size of the necrosis between the Leyland cypress isolates and the two $S$. cardinale isolates obtained from $C$. sempervirens. This seems to exclude any kind of host specialization or differentiation in pathogenicity among isolates from common and Leyland cypress. Furthermore, inoculations made with conidial suspensions of five isolates from Leyland cypress gave rise to necrotic processes in the stems of 3-year-old $C$. sempervirens plants. Hence, the inoculum of the fungus that is progressively increasing in the diseased Leyland cypress plantations, and the development of fruit bodies frequently observed on cankers, might favor the spread of the disease to neighboring common cypress trees and foster new outbreaks. Nevertheless, in the surveyed area, the disease currently appears to spread preferentially to Leyland cypress, whereas common cypress is only sporadically affected. It is possible that the prolonged contact between $S$. cardinale and $C$. sempervirens which occurred during epidemics in previous decades in central Italy has induced the common cypress to develop defenses, probably through a form of selection, in conjunction with the adopted sanitation measures that have removed many affected and susceptible trees throughout the territory. Leyland cypress trees are vulnerable due to their marked susceptibility to cypress canker and genetic uniformity, which is perpetuated by the agamic propagation of few genotypes.

In the south-central and southeastern United States, the disease is reported to be caused by S. unicorne (and, in Florida, by $S$. cupressi), and its occurrence is considered to be favored by prolonged drought periods which predispose Leyland cypress to infections and canker development $(3,24,40)$. According to Martinez et al. (24), Seiridium cankers enlarge up to three times faster on droughtstressed trees than on adequately irrigated trees. Among the three 
Seiridium fungal species causing cypress canker, S. unicorne is considered to be the least aggressive, often acting as an opportunistic pathogen, which can increase its impact on stressed Leyland cypress trees, ecologically unsuited to the hot and dry seasons typical of these regions of the United States. S. cardinale is considered a primary pathogen, causing cankers which generally show a greater development on healthy and fast-growing trees (growing in deep, fertile, and well-irrigated soils; 9,28). In our survey, new discolorations due to girdling and developing cankers were frequently observed during humid springs. Moreover, severe $S$. cardinale attacks occurred in plantations that showed good crown conditions in terms of growth, full color, and density, or in indirectly watered plantations (located in private gardens with meadow) without any sign of decline due to other reported stress factors (sparse foliage, stunted growth, chlorosis, and so on).

This small-scale survey allowed us to define and quantify the actual amount of damage observed on Leyland cypress on a larger scale in most regions of Italy, and underlines the fact that Leyland cypress is unsuited to areas where conditions are favorable to the development of $S$. cardinale because of its high susceptibility to attack by this pathogen. In these areas, the use of this tree should be discouraged, whereas it can be used successfully in cooler climates where the inoculum of the fungus is absent or scarce. For areas with a Mediterranean climate, some patented canker-resistant C. sempervirens clones available on the market can be used to replace Leyland cypress, particularly the clone Agrimed n.1, which has a shape suitable for barriers and windbreaks and is known for its vigor and its adaptation to Mediterranean climatic conditions and to different types of soil.

\section{Acknowledgments}

The research reported in this article was supported by Project CypFire (2GMED09-070; II Appel à Project-Programme MED 2009). We thank M. Haworth for his critical reading of the manuscript.

\section{Literature Cited}

1. Adams, R. P., Bartel, J. A., and Price, R. A. 2009. A new genus, Hesperocyparis, for the cypresses of the western hemisphere (Cupressaceae). Phytologia 91:160-185.

2. Armitage, J. 2011. The fertility of Leyland cypress. Plantsman 10:254-256.

3. Barnard, E. L., and Leahy, R. M., 2004. Cypress canker of Leyland cypress in Florida. Plant Pathol. Circ. No. 404, Fla. Dep. Agric. Cons. Serv.

4. Barnes, I., Roux, J., and Wingfield, M. J. 2001. Characterization of Seiridium spp. associated with Cypress canker based on $\beta$-tubulin and histone sequences. Plant Dis. 85:317-321.

5. Benson, M., Grand, L. F., and Jones, R. K., 2001. Disease of Leyland Cypress. North Carolina Cooperative Extension Service. Online publication. http://www.ces.ncsu.edu/depts/pp/notes/Ornamental/odin17/od17.htm

6. Bitner, R. L. 2007. Conifers for Gardens. An illustrated Encyclopedia. Timber Press, Portland, OR.

7. Chou, C. K. S. 1989. Morphological and cultural variation of Seiridium spp. from cankered Cupressaceae hosts in New Zealand. Eur. J. For. Pathol. 18:435-445.

8. Clark, R. 2008. Mother of all trees that sets neighbours at war revealed to have its accidental roots in Wales. Wales Online. Online publication. http:// www.walesonline.co.uk/news/wales-news/mother-trees-sets-neighbours-war2204948

9. Danti, R., Della Rocca, G., and Panconesi, A., 2013. Cypress canker. Pages 359-375 in: Infectious Forest Disease. G. Nicolotti and P. Gonthier, eds. CABI Press, Oxfordshire, England

10. Danti, R., Di Lonardo, V., Pecchioli, A., and Della Rocca, G. 2013. 'Le Crete 1' and 'Le Crete 2': two newly patented Seiridium cardinale cankerresistant cultivars of Cupressus sempervirens. For. Pathol. 43:204-210.

11. Danti, R., Raddi, P., Panconesi, A., Di Lonardo, V., and Della Rocca, G. 2006. 'Italico' and 'Mediterraneo': two Seiridium cardinale canker resistant Cypress cultivars of Cupressus sempervirens. Hortscience 41:13578-1359.

12. Della Rocca, G., Eyre, C. A., Danti, R., and Garbelotto, M. 2011. Sequence and SSR analyses of the fungal pathogen Seiridium cardinale indicate California is the most likely source of the Cypress canker epidemic for the Mediterranean region. Phytopathology 101:1408-1417.

13. Della Rocca, G., Osmundson, T., Danti, R., Pecchioli, A., Donnarumma, F., Casalone, E., and Garbelotto, M. 2013. AFLP analysis of California and Mediterranean populations of Seiridium cardinale provide insights on its origin, biology and spread pathways. For. Pathol. 43:211-221.

14. Gellini, R., and Grossoni, P. 1996. Botanica Forestale. I-Gimnosperme. Cedam, Padova, Italy.

15. Graniti, A. 1998 Cypress canker: a pandemic in progress. Annu. Rev. Phytopathol. 36:91-114.
16. Grasso, V., and Raddi, P., eds. 1979. Il Cipresso: malattie e difesa. Seminario CEE-Agrimed, Firenze, Italy.

17. Funk, A. 1974. Microfungi associated with dieback of native Cupressaceae in British Columbia. Can. Plant Dis. Surv. 54:166-168.

18. Hood, I. A., Gardner, J. F., Hood, R. J., Smith, B. M., and Phillips, G. D 2009. Pruning and cypress canker in New Zealand. Australas. Plant Pathol. 38:472-477.

19. Jackson, A. B., and Dallimore, W. 1926. A new hybrid conifer. Kew Bull 3:113-115

20. Kluepfel, M., Blake, J. H., and Gorsuch, C. S. 2001. Leyland Cypress Diseases, Insects \& Related Pests. The Clemson University Cooperative Extension Service. Online publication. http://www.clemson.edu/extension/hgic/ pests/pdf/hgic2004.pdf

21. Little, D. P. 2006. Evolution and circumscription of the true cypresses ( $\mathrm{Cu}$ pressaceae: Cupressus). Syst. Bot. 31:461-480.

22. Little, D. P., Schwarzbach, A. E., Adams, R. P., and Hseih, C. F. 2004. The circumscription and phylogenetic relationships of Callitropsis and the newly described genus Xanthocyparis (Cupressaceae). Am. J. Bot. 91:1871-1880.

23. Mao, K., Hao, G., Liu, J., Adams, R. P., and Milne, R. I. 2010. Diversification and biogeography of Juniperus (Cupressaceae): Variable diversification rates and multiple intercontinental dispersals. New Phytol. 188:254-272.

24. Martinez, A., Woodward, J. W., and Pearce, M. 2012. Diseases of Leyland Cypress In the Landscape. Bull. 1229, The University of Georgia and Ft. Valley State University, Athens.

25. Mitchell, A. F. 1985. Clones of Leyland cypress. IDS Yearbook 1985:97100.

26. Mordue, J. E. M. 1976. CMI Description of Pathogenic Fungi and Bacteria, no. 514. CMI, Kew, Surrey, UK.

27. Mujica, F., Vergara, C., and Oehrens, E. 1980. Flora Fungosa Chilena, 2nd ed. Ciencias Agricolas 5, Universidad de Chile, Santiago, Chile.

28. Panconesi, A. 1990. Pathological disorders in the Mediterranean basin Pages 54-81 in: Agriculture-AGRIMED Research Programme: Progress in EEC Research on Cypress Diseases. Rep. EUR 12493 EN. J. Ponchet, ed. Commission of the European Communities, Brussels

29. Parrini, C., and Panconesi, A. 1981. Attacchi di Seiridium (Coryneum) cardinale (Wag.) Sutton e Gibson su alcune Cupressaceae in vivaio. Inf. Fitopatol. 9:7-15.

30. Ponchet, J., and Andreoli, C. 1990. Compartmentalization and reaction in the host. Pages 96-111 in: Agriculture-AGRIMED Research Programme: Progress in EEC Research on Cypress Diseases. Rep. EUR 12493 EN. J. Ponchet, ed. Commission of the European Communities, Brussels.

31. Raddi, P., and Panconesi, A. 1981. Cypress canker disease in Italy: biology, control, possibilities and genetic improvement for resistance. Eur. J. For. Pathol. 11:340-347.

32. Reid, A., 2004. Cypress canker (caused by Seiridium spp.). GardenNote, Department of Agriculture and Food and the State of Western Australia. Online publication. http://www.agric.wa.gov.au/objtwr/imported_assets/ content/fcp/sc/tree/gn2004 013.pdf

33. Roversi, P. F. 2010. Avversità degli alberi e delle foreste. In: Rapporto sullo stato delle foreste in Toscana (RaFT) 2009. Regione Toscana ARSIA, Litograf Editor, Perugia, Italy.

34. Smith, A. J. 2010. Seiridium canker of Leyland Cypress. Document FOR279, School of Forest Resources and Conservation, Florida Cooperative Extension Service, Institute of Food and Agricultural Sciences, University of Florida. Online publication. http://edis.ifas.ufl.edu/pdffiles/FR/FR34100.pdf

35. Stone, C., Matsuki, M., and Carnegie, A. 2003. Pest and disease assessment in young eucalypt plantations: Field manual for using the Crown Damage Index. M. Parsons, ed. National Forest Inventory, Bureau of Rural Sciences, Canberra, Australia.

36. Strouts, R. G. 1973. Canker of cypresses caused by Corynueum cardinale Wag. in Britain. Eur. J. For. Pathol. 3:13-24.

37. Sutton, B. C., and Gibson, I. A. S. 1972. Seiridium cardinale. CMI Descr. Pathogenic Fungi Bacteria No. 326.

38. Swart, H. J. 1973. The fungus causing cypress canker. Trans. Br. Mycol. Soc. 61:71-82.

39. Terry, R., Bartel, J. A., and Adams, R. P. 2012. Phylogenetic relationships among the New World cypresses (Hesperocyparis; Cupressaceae): Evidence from noncoding chloroplast DNA sequences. Plant Syst. Evol. 298:1987-2000.

40. Tisserat, N. A., Nus, A., and Barnes, L. W. 1991. A canker disease of the Cupressaceae in Kansas and Texas caused by Seiridium unicorne. Plant Dis. 75:138-140.

41. Urbasch, I. 1993. Natural occurrence of Seiridium cardinale on Thuja in Germany. J. Phytopathol. 137:189-194.

42. Van der Werff, H. S. 1988. Cypress canker in New Zealand plantations N.Z. J. For. Sci. 18:101-108.

43. Vann, S., 2006. Branch Canker and Dieback of Leyland Cypress. Division of Agriculture Research Extension, University of Arkansas. Online publication. http://www.uaex.edu/Other_Areas/publications/PDF/FSA-7536.pdf

44. Wagener, W. W. 1939. The canker of Cupressus induced by Coryneum cardinale n. sp. J. Agric. Res. 58:1-47.

45. Wimbush, S. H. 1944. Canker of Monterey cypress in Kenya. Empire For. J. 23:74.

46. Wingfield, M. J., and Swart, W. J. 1988. Cypress canker in South Africa. In: Abstr. 5th Int. Congress Plant Pathol. Kyoto, Japan. 